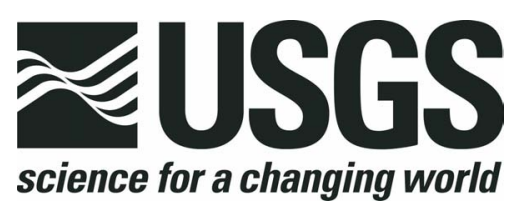

\title{
Representative bulk composition of oil types for the 2002 U.S. Geological Survey Resource Assessment of National Petroleum Reserve in Alaska
}

by Paul G. Lillis ${ }^{1}$

Open-File Report 03-407

2003

This report is preliminary and has not been reviewed for conformity with U.S. Geological Survey editorial standards or with the North American Stratigraphic Code. Any use of trade, firm, or product names is for descriptive purposes only and does not imply endorsement by the U.S. Government.

U.S. DEPARTMENT OF THE INTERIOR

U.S. GEOLOGICAL SURVEY

${ }^{1}$ U.S. Geological Survey, Denver, Colorado 


\title{
TABLE OF CONTENTS
}

\author{
Abstract \\ Introduction \\ Kuna-Lisburne source rock unit \\ Shublik-Otuk source rock unit \\ Kingak-Blankenship source rock unit \\ Pebble-GRZ-Torok source rock unit \\ Mixed oil types \\ Summary

\section{References}

Table 1

Table 2

Figure 1

Figure 2 


\begin{abstract}
Bulk oil composition is an important economic consideration of a petroleum resource assessment. Geological and geochemical interpretations from previous North Slope studies combined with recently acquired geochemical data are used to predict representative oil gravity ( ${ }^{\circ} \mathrm{API}$ ) and sulfur content (wt.\% S) of the oil types for the 2002 U.S. Geological Survey resource assessment of the National Petroleum Reserve of Alaska (NPRA). The oil types are named after their respective source rock units and include Kuna-Lisburne, Shublik-Otuk, Kingak-Blankenship, and Pebble-GRZ-Torok. The composition of the oil $\left(24^{\circ}\right.$ API, 1.6 wt.\% S) in the South Barrow 12 well was selected as representative of Kuna-Lisburne oil. The average gravity and sulfur values ( $23^{\circ} \mathrm{API}$ and $1.6 \mathrm{wt} . \% \mathrm{~S}$, respectively) of the Kuparuk field were selected to be representative of Shublik-Otuk oil type. The composition of the oil $\left(39^{\circ} \mathrm{API}, 0.3\right.$ wt.\% S) from the Alpine field discovery well (ARCO Bergschrund 1) was selected to be representative of Kingak-Blankenship oil. The oil composition ( $\left.37^{\circ} \mathrm{API}, 0.1 \mathrm{wt} . \% \mathrm{~S}\right)$ of Tarn field was considered representative of the Pebble-GRZ-Torok oil type in NPRA.
\end{abstract}

\title{
Introduction
}

An important economic consideration of a petroleum resource assessment is the bulk composition of the petroleum charge in the assessment unit or play, especially its specific gravity and sulfur content. For example, crude oil with high API gravity (American Petroleum Institute gravity scale in ${ }^{\circ} \mathrm{API}$ ) and low sulfur content (wt.\% S) has more economic value than low API gravity, high sulfur oil. The geochemical composition of oil is controlled by the kerogen composition of the source rock as well as by post-expulsion alteration effects such as biodegradation and thermal cracking. Therefore, it is critical to identify and map the source rock for an assessed play and characterize the composition of the hydrocarbon charge. This report incorporates geological and geochemical interpretations from previous North Slope studies (Magoon and Claypool, 1981, 1988; Hughes and Holba, 1988; GeoMark, 1997; Sedivy and others, 1987; Lillis and others, 1999; Threlkeld and others, 2000; Masterson, 2001) with recently acquired geochemical data to predict a representative bulk composition of the oil types for the 2002 U.S. Geological Survey (USGS) resource assessment plays of the National Petroleum Reserve of Alaska (NPRA).

Oil source rocks recognized in NPRA as being important for this assessment include, from oldest to youngest, Kuna Formation, Lisburne Group, Shublik Formation, Otuk Formation, Kingak Shale, pebble shale unit, gamma ray zone (GRZ) and Torok Formation ffig. 1). These units contain oil-prone kerogen and have been correlated with oil accumulations or oil-stained rocks in the area (fig. 2). For the 2002 resource assessment, rock units known to be widely distributed in the NPRA (Lisburne, Shublik, and Kingak) have been considered along with their distal, condensed equivalents (Kuna, Otuk, and Blankenship, respectively) that are 
present in the Brooks Range and foothills of southern NPRA (see Bird, this volume). These stratigraphic units with similar age and kerogen composition are referred to in this assessment by hyphenated source rock names: Kuna-Lisburne, Shublik-Otuk, Kingak-Blankenship, and Pebble-GRZ-Torok; the geologic and geochemical rationale for these combinations is discussed further below. The Hue Shale and Canning Formation are located too far away to be considered source rocks for oil within NPRA, but they are effective source rocks east of Prudhoe Bay (Lillis and others, 1999). Coal within the Kekiktuk Conglomerate is likely to be only a source for gas and will not be discussed further.

This report assigns the representative bulk composition of the oil types based on the data of crude oil interpreted to be derived from a single source rock unit. However, oil-source rock correlation on the North Slope is more difficult because of mixed oil types and variation in organic facies within a source formation. A further complication is that crude oil composition is influenced by non-genetic effects, such as thermal maturity of the source rock at the time of expulsion, and biodegradation and cracking of the oil after expulsion. All these effects must be recognized and taken into account when assigning a representative bulk composition.

For each play of the 2002 NPRA assessment, the assessment geologist determined (1) the mostly likely source of oil based upon the distribution of thermally mature source rock, (2) the time of oil generation with respect to the time of trap formation, and (3) whether favorable "plumbing" geometry existed at the time when oil migrated into the play area. Each of the 16 oil plays was thus assigned an API gravity and sulfur content based on the expected oil type. When more than one oil type is predicted in a play, then the assigned API gravity and sulfur content reflect the mixture of the end member types.

\section{Kuna-Lisburne source rock unit}

The Lower Mississippian to Lower Permian Lisburne Group is widely distributed throughout the North Slope, and consists predominantly of shallow marine carbonate rocks, but locally consists of deep marine shale, chert, fine-grained limestone and dolomite. North of the

Brooks Range (fig. 2) the Lisburne is predominantly platform carbonates low in organic carbon content with sporadic interbeds of organic-rich shale (Masterson, 2001). In the central and western Brooks Range the Lisburne Group consists predominantly of the deep marine Kuna Formation (Mull and others, 1982) and is generally organic-rich (Tailleur, 1964; Bird and Jordan, 1977; Magoon and Bird, 1988; Banet and Evans, 2002). The Lisburne has been proposed as an oil source rock by several workers (Bird and Jordan, 1977; Anders and others, 1985; Huang and others, 1985; Hughes and others, 1985; Keal and Dow, 1985; Magoon and Bird, 1988; GeoMark, 1997; Lillis and others, 1999; Holba, Wilson, and others, 2000, 2001; Masterson, 2001, Lillis and others, 2002), and work in progress by the USGS (Lillis, unpublished data) shows that the shale facies is likely the primary oil source. The KunaLisburne is here designated a source rock unit because the Kuna Formation as well as other unnamed thin beds of organic-rich source rocks are within the Lisburne Group.

Oil occurrences believed to be derived from the Kuna-Lisburne source rock unit are widely scattered and few in number. The only oil samples of Kuna-Lisburne for which there are API gravity and sulfur data are from the J.W. Dalton 1, KRU 2F-20,Mikkelsen Bay State 1 South Barrow 12, South Barrow 17, and South Barrow 19 wells (fig. 2. table 1). However, 
there are problems connected with each of these samples. The oil gravity and sulfur content of the Dalton sample has been altered by biodegradation (Magoon and Claypool, 1988) and the KRU 2F-20 sample was generated at high maturity (Masterson, 2001). The Mikkelsen well is located the farthest from NPRA, and may have a slightly different oil composition because of possible lateral source facies variation within the Kuna-Lisburne. The South Barrow oil samples were proposed to be Kuna-Lisburne oils (GeoMark, 1997) but more recent geochemical studies suggest that they are derived from the Shublik-Otuk source rock unit (Holba, Ellis, and others, 2000). Consequently, the gravity and sulfur content of Kuna-Lisburne type oil estimated for the assessment has a higher degree of uncertainty than the other oil types. For the assessment, the composition of the South Barrow 12 oil (24\% API, 1.6 wt.\% S) was selected as representative of Kuna-Lisburne oil (table 1).

\section{Shublik-Otuk source rock unit}

The Shublik-Otuk source rock unit includes the widespread Shublik Formation and the chert and limestone members of the Otuk Formation in the central and western Brooks Range. The Middle and Upper Triassic Shublik Formation is widely regarded as the source rock for the largest volume of petroleum on the North Slope of Alaska. Many of the oil fields, including the giant Prudhoe Bay field, contain a mixture of Shublik and other oil types (Seifert and others, 1980; Claypool and Magoon, 1985; Sedivy and others, 1987; GeoMark, 1997; Masterson, 2001), so the oil composition of these fields is not wholly representative of the Shublik-Otuk oil type. However, oil in the Kuparuk field (fig. 2) is predominantly derived from the Shublik Formation (Masterson and others, 1997, 2001; Masterson, 2001). Accordingly, the gravity and sulfur values used for this assessment are $23^{\circ} \mathrm{API}$ and $1.6 \mathrm{wt} . \% \mathrm{~S}$, respectively, based on the average composition of Kuparuk field (table 2).

The age-equivalent strata originally mapped as the Shublik Formation in the central and western Brooks Range was renamed the Otuk Formation (Mull and others, 1982) and has been identified as the source rock for the oil found in outcrops in the central Brooks Range Foothills (Lillis and others, 2002). Bird (1994) considered the chert and limestone members of the Otuk to be lateral time-stratigraphic equivalents to the Shublik in his characterization of the Ellesmerian petroleum system of the North Slope. Similarly, the Shublik and Otuk are considered here as a single source rock unit following the same rationale, although there are noted differences in biomarker composition (Lillis and others, 2002) and lithology (Mull and others, 1982) between the two formations.

\section{Kingak-Blankenship source rock unit}

The Kingak-Blankenship source rock unit includes the widespread Kingak Shale and the partly age-equivalent Blankenship Member of the Otuk Formation in the Brooks Range. Jurassic marine shales (Kingak Shale) were first proposed by Morgridge and Smith (1972) as a possible source of oil on the North Slope. Seifert and others (1980) presented geochemical evidence that the Kingak Shale is the source rock for oil recovered from a drill-stem test from the Kavearak 32-25 well (Milne Point field) and that the Kingak is a significant oil contributor to Prudhoe Bay field (fig. 2). This interpretation has been supported by subsequent studies (Claypool and Magoon, 1985; Premuzac and others, 1986; Sedivy and others, 1987; GeoMark, 
1997; Holba, Wilson, and others, 2000, Masterson, 2001). Until Alpine field was discovered, only a few small oil accumulations with pure Kingak oil had been identified (GeoMark, 1997). Because Alpine field is the largest known accumulation of Kingak oil (Masterson, 2001) and is located adjacent to NPRA, the gravity and sulfur content $\left(39^{\circ} \mathrm{API}, 0.3 \mathrm{wt} . \% \mathrm{~S}\right)$ of the oil from the discovery well (ARCO Bergschrund 1) were used for this assessment as representative of Kingak-Blankenship oil (table 2).

The Blankenship Member of the Otuk Formation (Mull and others, 1982) is the southern, distal stratigraphic equivalent of the Kingak Shale, and Bird (1994) combined the Blankenship with the Kingak in his calculations of the Ellesmerian petroleum system. Work in progress at the USGS (Lillis, unpublished data) shows that the Blankenship bitumen extract composition is very similar to the oil derived from the Kingak Shale. Therefore, the Blankenship is combined with the Kingak as a single source rock unit.

\section{Pebble-GRZ-Torok source rock unit}

The Pebble-GRZ-Torok source rock unit includes a stack of three closely related Lower Cretaceous organic-rich rock units, the pebble shale unit (Pebble), the gamma-ray zone (GRZ), and the lower part of the Torok Formation. Lower Cretaceous source rocks have long been recognized on the North Slope (Morgridge and Smith, 1972; Jones and Speers, 1976), and an early oil-source rock correlation study by Seifert and others (1980) showed that Lower Cretaceous post-Neocomian source rock is a significant contributor of oil to Prudhoe Bay field. These post-Neocomian strata were interpreted by Carmen and Hardwick (1983) to be the "highly radioactive zone" or HRZ (also called the "gamma-ray zone" or GRZ, Tailleur and others, 1978) within the informally named pebble shale unit (Molenaar, 1981, 1983). The pebble shale unit has been differentiated from the GRZ within NPRA (Bird, this volume) and east of NPRA (Molenaar and others, 1987). Work in progress at the USGS indicates that the pebble shale unit may be a potential source of oil in northeastern NPRA. The Lower Cretaceous Torok Formation lies above the GRZ and below the Cretaceous Nanushuk Group (Bird, 1985) and is most likely a source rock of oil (and gas) in NPRA (Magoon and Bird, 1985; Connan and others, 1985, Lillis and others, 2002).

Following previous studies (Claypool and Magoon, 1985; GeoMark, 1997), the pebble shale unit, GRZ, and Torok source rock intervals are here considered a single source rock unit because this conformable package of Lower Cretaceous strata has a similar kerogen composition (Magoon and Bird, 1988), and is likely to produce a similar low sulfur (0.1 wt.\% S) oil. However, oil derived from the GRZ part of the Hue Shale east of NPRA has a higher sulfur content (0.5 to $1.0 \mathrm{wt} . \% \mathrm{~S}$ ) (Lillis and others, 1999). The largest known accumulation of Pebble-GRZ-Torok oil is Tarn field (Masterson, 2001) and the bulk composition $\left(37^{\circ} \mathrm{API}, 0.1\right.$ wt.\% S) was considered representative for this source rock unit in NPRA fig. 2, table 2).

\section{Mixed oil types}

For some of the plays of the 2002 NPRA assessment, the assessment geologist predicted more than one oil type. In these cases a representative bulk composition was based on a 50:50 mix of two end-member oil types table 2). For example, a mixture of Shublik-Otuk 
and Pebble-GRZ-Torok oil types is considered to have a gravity of $30^{\circ} \mathrm{API}$ and a sulfur content of 1.0 weight percent $S$.

\section{Summary}

This report assigns a representative gravity and sulfur content of the NPRA oil types predicted to charge the plays in the 2002 NPRA resource assessment. The oil types are believed to be derived from source rock units known to be widely distributed in the NPRA (Lisburne, Shublik, and Kingak) and their distal, condensed equivalents (Kuna, Otuk, and Blankenship, respectively). The oil types are named after their respective source rock units and include Kuna-Lisburne, Shublik-Otuk, Kingak-Blankenship, and Pebble-GRZ-Torok.

The largest known accumulation of each oil type (except Kuna-Lisburne) was selected as the representative composition. The average gravity and sulfur values of Kuparak field $\left(23^{\circ} \mathrm{API}\right.$ and $\left.1.6 \mathrm{wt} . \% \mathrm{~S}\right)$ were considered to be representative of the Shublik-Otuk oil. The composition of the oil from the discovery well of Alpine field $\left(39^{\circ} \mathrm{API}, 0.3 \mathrm{wt} . \% \mathrm{~S}\right)$ was used for the assessment as representative of Kingak-Blankenship oil. The composition ( $37^{\circ} \mathrm{API}, 0.1$ wt.\% S) of Tarn field was considered to be representative for Pebble-GRZ-Torok oil in NPRA. The composition of the South Barrow 12 oil ( $24^{\circ}$ API gravity, 1.6 wt.\% S) was selected as representative of Kuna-Lisburne oil.

\section{References}

Anders, D.E., King, J.D., and Lubeck, Sr.C., 1985, Correlation of oils and source rocks from the Alaskan North Slope, in Magoon, L.B. and Claypool, G.E., eds., 1985, Alaska North Slope Oil/Source Rock Correlation Study: American Association of Petroleum Geologists Studies in Geology no. 20, p. 281-303.

Banet, A.C. and Evans, K.R., 2002, Paleo source-rock characteristics of the Kuna Formation in the Western Brooks Range [abs]: American Association of Petroleum Geologists Bulletin, v. 86, p. 1135 .

Bird, K.J., 1985, The framework geology of the North Slope of Alaska as related to oil-source rock correlations, in Magoon, L.B. and Claypool, G.E., eds., Alaska North Slope oil-source rock correlation study: American Association of Petroleum Geologists Studies in Geology no. 20 , p. 3-29.

1994, Ellesmerian(!) petroleum system, North Slope of Alaska, U.S.A., in Magoon, L.B., and Dow, W.G., eds., The petroleum system-from source to trap: American Association of Petroleum Geologists Memoir 60, p. 339-358. 
Bird, K.J. and Jordan, C.F., 1977, Lisburne Group (Mississippian and Pennsylvanian), potential major hydrocarbon objective of Arctic Slope, Alaska: American Association of Petroleum Geologists Bulletin, v. 61, p. 1493-1512.

Carmen, G.J., and Hardwick, P., 1983, Geology and regional setting of Kuparuk oil field, Alaska: American Association of Petroleum Geologists Bulletin, v.67, p. 1014-1031.

Claypool, G.E. and Magoon, L.B., 1985, Comparison of oil-source rock correlation data for Alaska North Slope: techniques, results, and conclusions, in Magoon, L.B. and Claypool, G.E., eds., 1985, Alaska North Slope Oil/Source Rock Correlation Study: American Association of Petroleum Geologists Studies in Geology no. 20, p. 49-81.

Connan, J., DesAutels, D.A., and Aldridge, A.K., 1985, Petroleum geochemistry of North Slope Alaska: source rocks, crude oil properties, and migration of hydrocarbons, in Magoon, L.B. and Claypool, G.E., eds., 1985, Alaska North Slope Oil/Source Rock Correlation Study: American Association of Petroleum Geologists Studies in Geology no. 20, p. 243-279.

GeoMark, 1997, The petroleum geochemistry of the North Slope of Alaska and the BeaufortMackenzie Delta basin, by Craig F. Schiefelbein, Harold A. Illich, Stephen W. Brown and John E. Zumberge, GeoMark Research, Inc. Houston, Texas.

Holba, A.G., Ellis, L., Decker, P., Wilson, G., Watts, A., and Masterson, D., 2000, Organic geochemistry of gas fields flanking the Avak impact structure, western NPRA, North Slope, Alaska: Alaska Geological Society and Geophysical Society of Alaska, 2000 Science and Technology Conference, Anchorage, Alaska, April 13, 2000, abstracts and program.

Holba, A.G., Wilson, G., Decker, P., Garrard, R. and Ellis, L., 2000, North Slope, Alaska petroleum systems: Alaska Geological Society and Geophysical Society of Alaska, 2000 Science and Technology Conference, Anchorage, Alaska, April 13, 2000, abstracts and program.

2001, Western North Slope, Alaska petroleum systems: 20th International Meeting on Organic Geochemistry, September 10-14, 2001, Nancy, France, Abstracts Volume 1, p. 358.

Huang, W.Y., Grizzle, P.L., and Haney, F.R., 1985, Source rock-crude oil correlations: Alaskan North Slope, in Magoon, L.B. and Claypool, G.E., eds., 1985, Alaska North Slope Oil/Source Rock Correlation Study: American Association of Petroleum Geologists Studies in Geology no. 20, p. 557-570.

Hughes, W.B. and Holba, A.G., 1988, Relationship between crude oil quality and biomarker patterns: Organic Geochemistry, v. 13, p. 15-30. 
Hughes, W.B., Holba, A.G. and Miller, D.E., 1985, North Slope Alaska oil-rock correlation study, in Magoon, L.B. and Claypool, G.E., eds., 1985, Alaska North Slope Oil/Source Rock Correlation Study: American Association of Petroleum Geologists Studies in Geology no. 20, p. 379-402.

Keal, J.E. and Dow, W.G., 1985, Alaskan North Slope oils and source rocks, in Magoon, L.B. and Claypool, G.E., eds., 1985, Alaska North Slope Oil/Source Rock Correlation Study: American Association of Petroleum Geologists Studies in Geology no. 20, p. 85-94.

Jones, H.P. and Speers, R.G., 1976, Permo-Triassic reservoirs of Prudhoe Bay field, North Slope, Alaska, in Braunstein, J., ed., North American Oil and Gas Fields: American Association of Petroleum Geologists Memoir 24, p. 23-50.

Lillis, P.G., King, J.D., Warden, A., and Pribil, M.J., 2002, Oil-source rock correlation studies, Central Brooks Range foothills and National Petroleum Reserve, Alaska (NPRA) [abs]: American Association of Petroleum Geologists Bulletin, v. 86, p. 1150.

Lillis, P.G., Lewan, M.D., Warden, A., Monk, S.M. and King, J.D., 1999, Identification and characterization of oil types and their source rocks, in The Oil and Gas Resource Potential of the 1002 Area, Arctic National Wildlife Refuge, Alaska, by ANWR Assessment Team, U.S. Geological Survey Open-File Report 98-34, Chapter OA, 101 p.

Magoon, L.B., 1988, The petroleum system-a classification scheme for research, exploration, and resource assessment, in Magoon, L.B., ed., Petroleum systems of the United States: U.S. Geological Survey Bulletin 1870, p. 2-15.

Magoon, L.B. and Bird, K.J., 1985, Alaskan North Slope petroleum geochemistry for the Shublik Formation, Kingak Shale, Pebble Shale Unit, and Torok Formation, in Magoon, L.B. and Claypool, G.E., eds., Alaska North Slope oil-source rock correlation study: American Association of Petroleum Geologists Studies in Geology no. 20, p. 31-48.

1988, Evaluation of petroleum source rocks in the National Petroleum reserve in Alaska, using organic-carbon content, hydrocarbon content, visual kerogen, and vitrinite reflectance, in Gryc, G., ed., Geology and exploration of the National Petroleum Reserve in Alaska, 1974 to 1982: U.S. Geological Survey Professional Paper 1399, p. 381-450.

Magoon, L.B., Bird, K.J., Burruss, R.C., Hayba, D., Houseknecht, D.W., Keller, M.A., Lillis, P.G., and Rowan, E.L., 1999, Evaluation of hydrocarbon charge and timing using the petroleum system, in The Oil and Gas Resource Potential of the 1002 Area, Arctic National Wildlife Refuge, Alaska, by ANWR Assessment Team, U.S. Geological Survey Open-File Report 98-34, Chapter PS, 66 p.

Magoon, L.B. and Claypool, G.E., 1981, Two oil types on North Slope of Alaska implications for exploration: American Association of Petroleum Geologists Bulletin, v. 65 , p. 644-652. 
1988, Geochemistry of oil occurrences, National Petroleum Reserve in Alaska, in Gryc, G., ed., Geology and exploration of the National Petroleum Reserve in Alaska, 1974 to 1982: U.S. Geological Survey Professional Paper 1399, p. 519-549.

Magoon, L.B., Lillis, P.G., and Lampe, C., 2002, Petroleum systems of the Alaskan North Slope - a progress report [abs]: American Association of Petroleum Geologists Bulletin, v. 86, p. 1151.

Magoon, L.B., Woodward, P.V., Banet, A.C., Griscom, S.B. and Daws, T.A., 1987, Thermal maturity, richness, and type of organic matter of source-rock units, in Bird, K.J. and Magoon, L.B., eds., Petroleum Geology of the Northern part of the Arctic National Wildlife Refuge, Northeastern Alaska: U.S. Geological Survey Bulletin 1778, p. 127-179.

Masterson, W.D., 2001, Petroleum filling history of central Alaskan North Slope fields: Dallas, The University of Texas at Dallas, Ph.D. dissertation 222 p.

Masterson, W.D., Dzou, L.I.P., Holba, A.G., Fincannon, A.L., and Ellis, L., 2001, Evidence for biodegradation and evaporative fractionation in West Sak, Kuparuk an Prudhoe Bay field areas, North Slope, Alaska: Organic Geochemistry, v. 32, p. 411-441.

Masterson, W.D., Holba, A., and Dzou, L., 1997, Filling history of America's two largest oil fields: Prudhoe Bay and Kuparuk, North Slope, Alaska [abs]: American Association of Petroleum Geologists Annual Convention Abstracts and Program, v. 6, p. A77.

Molenaar, C.M., 1981, Depositional history and seismic stratigraphy of Lower Cretaceous rocks, National Petroleum Reserve in Alaska, and adjacent areas: U.S. Geological Survey Open File Report 81-1084, 45p.

1983, Depositional relations of Cretaceous and Lower Tertiary rocks, Northeastern Alaska: American Association of Petroleum Geologists Bulletin: v. 67, p.1066-1080.

Molenaar, C.M., Bird, K.J., and Kirk, A.R., 1987, Cretaceous and Tertiary stratigraphy of Northeastern Alaska, in Tailleur, I. and Weimer, P., eds., Alaskan North Slope Geology: Pacific Section, Society of Economic Paleontologists and Mineralogists and Alaska Geological Society, Book 50, p. 513-528.

Morgridge, D.L. and Smith, W.B., 1972, Geology and discovery of Prudhoe Bay field, eastern Arctic Slope, Alaska, in King, R.E., ed., Stratigraphic oil and gas fields-classification, exploration methods, and case histories: American Association of Petroleum Geologists Memoir 16, p. 489-501.

Mull, C.G., Tailleur, I.L., Mayfield, C.F., Ellersieck, I., and Curtis, S., 1982, New Upper Paleozoic and Lower Mesozoic stratigraphic units, Central and Western Brooks Range, Alaska: American Association of Petroleum Geologists Bulletin, v. 66, p. 348-362. 
Premuzic, E.T., Gaffney, J.S. and Manowitz, B., 1986, The importance of sulfur isotope ratios in the differentiation of Prudhoe Bay crude oils: Journal of Geochemical Exploration, v. 26, p. 151-159.

Sedivy, R. A., Penfield, I.E., Halpern, H.I., Drozd, R.J., Cole, G.A. and Burwood, R., 1987, Investigation of source rock-crude oil relationships in the northern Alaska hydrocarbon habitat, in Tailleur, I. and Weimer, P., eds., Alaskan North Slope Geology: Pacific Section, Society of Economic Paleontologists and Mineralogists and Alaska Geological Society, Book 50 p. 169-179.

Seifert, W.K., Moldowan, J.M. and Jones, J.W., 1980, Application of biological marker chemistry to petroleum exploration, in World Petroleum Congress, 10th, Bucharest, Romania, 1979, Proceedings: London, Heyden and Son, Ltd., p. 425-440.

Tailleur, I.L., 1964, Rich oil shale from northern Alaska, Part 148 of Short papers in geology and hydrology: U.S. Geological Survey Professional Paper 475-D, p. D131-D133.

Tailleur, I.L., Pessel, G.H., and Engwicht, S.E., 1978, Folio, eastern North Slope petroleum province: U.S. Geological Survey Miscellaneous Field Studies Map MF 928A, 8 p.

Threlkeld, C.N., Obuch, R.C., and Gunther, G.L., 2000, Organic geochemistry data of Alaska: USGS Digital Data Series DDS-59. 
Table 1. API gravity and sulfur content of oil derived from Kuna-Lisburne source rock unit.

\begin{tabular}{lccl}
\hline Well & $\begin{array}{l}\text { Gravity } \\
\left({ }^{\circ} \text { API }\right)\end{array}$ & $\begin{array}{l}\text { Sulfur } \\
(\text { wt. } \%)\end{array}$ & Data Source \\
\hline J.W. Dalton 1 & 13 & 2.5 & Magoon and Claypool (1988) \\
KRU 2F-20 & 33 & 0.7 & Masterson (2001) \\
Mikkelsen Bay State 1 & 25 & 1.4 & Lillis and others (1999) \\
S. Barrow 12 & 24 & 1.6 & GeoMark (1997) \\
S. Barrow 17 & 19 & 1.9 & Magoon and Claypool (1988) \\
S. Barrow 19 & 21 & 1.7 & Magoon and Claypool (1988)
\end{tabular}

Table 2. API gravity and sulfur content of oil types used in the 2002 NPRA assessment.

\begin{tabular}{llll}
\hline Source rock unit & $\begin{array}{l}\text { Gravity } \\
\left({ }^{\circ} \mathrm{API}\right)\end{array}$ & $\begin{array}{l}\text { Sulfur } \\
(\text { wt. } \%)\end{array}$ & Data source \\
\end{tabular}

\begin{tabular}{llll}
\hline Kuna-Lisburne & 24 & 1.6 & GeoMark (1997) \\
Shublik-Otuk & 23 & 1.6 & Masterson (2001) \\
Kingak-Blankenship & 39 & 0.3 & Masterson (2001) \\
Pebble-GRZ-Torok & 37 & 0.1 & Masterson (2001)
\end{tabular}

Shublik-Otuk and Pebble-

GRZ-Torok (50:50 mix)
Shublik-Otuk and Kingak

Blankenship (50:50 mix) $\quad 30 \quad 1.0$ 


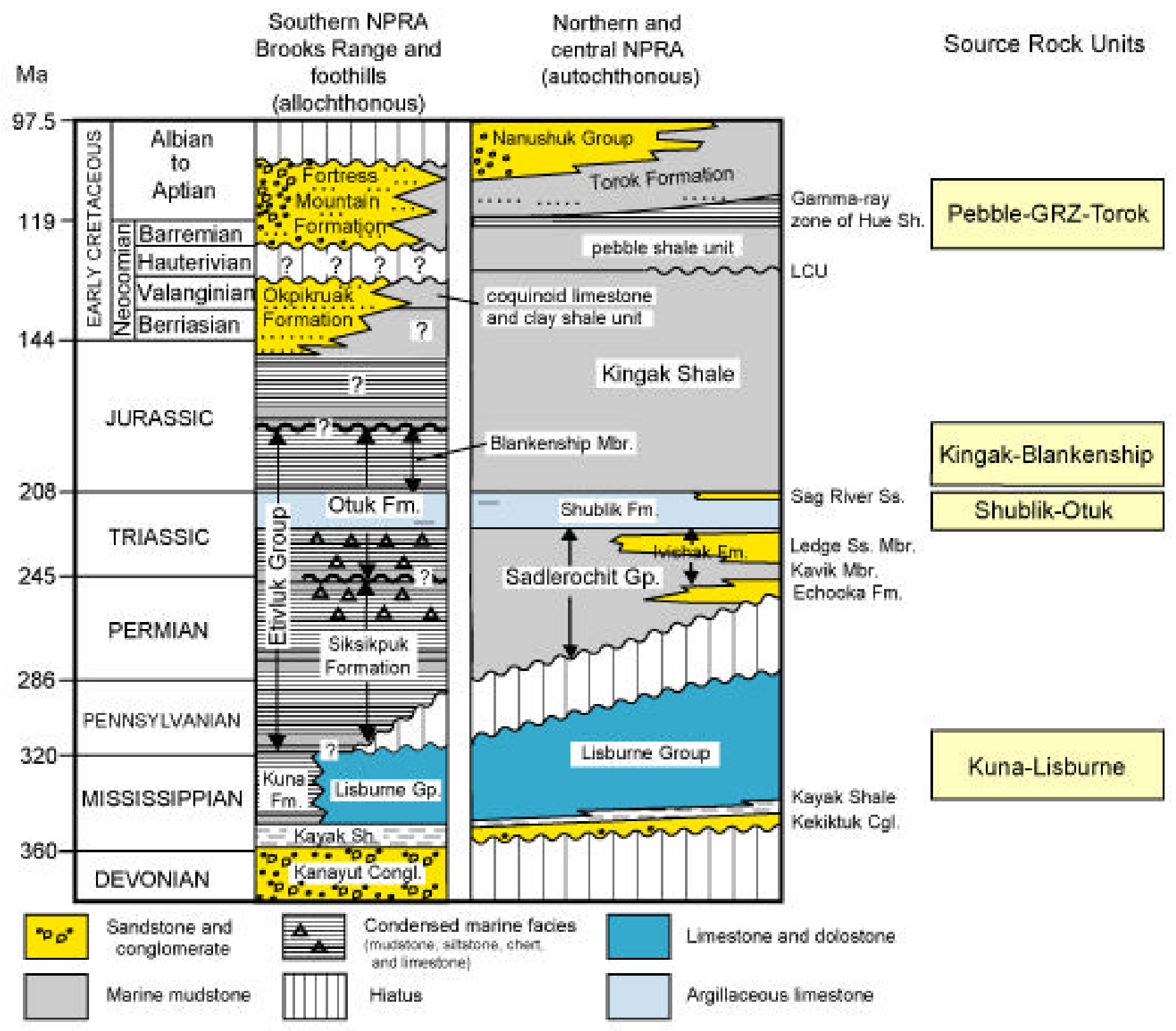

Figure 1. Stratigraphic summary of NPRA (modified from Bird, this volume), and oil source rock units used in the 2002 assessment LCU, Lower Cretaceous unconformity. 


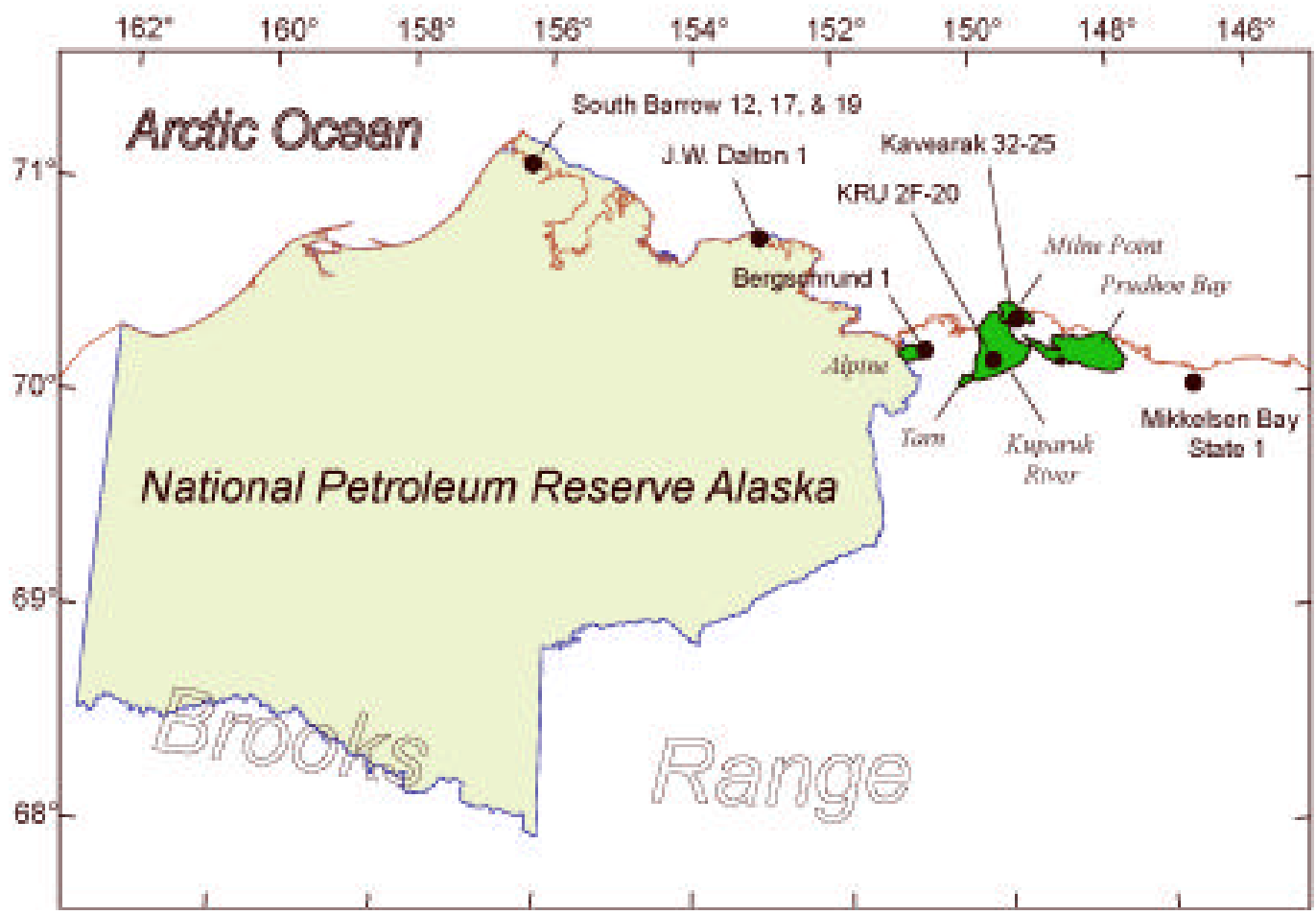

Figure 2. Index map of the Nationsi Petroleum Ricserve Alaska (NPRA). Ol ficlds (green areas) and wol locabione (back dots) discussed in toxt. 